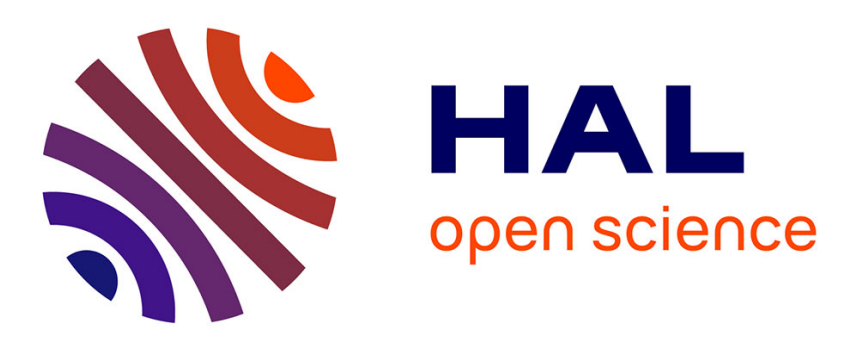

\title{
Mass Spectrometric Study of Thermolysis Mechanism of Metal Acetylacetonates Vapour
}

\author{
A. Bykov, A. Turgambaeva, I. Igumenov, P. Semyannikov
}

\section{To cite this version:}

A. Bykov, A. Turgambaeva, I. Igumenov, P. Semyannikov. Mass Spectrometric Study of Thermolysis Mechanism of Metal Acetylacetonates Vapour. Journal de Physique IV Proceedings, 1995, 05 (C5), pp.C5-191-C5-197. 10.1051/jphyscol:1995521 . jpa-00253846

\section{HAL Id: jpa-00253846 https://hal.science/jpa-00253846}

Submitted on 1 Jan 1995

HAL is a multi-disciplinary open access archive for the deposit and dissemination of scientific research documents, whether they are published or not. The documents may come from teaching and research institutions in France or abroad, or from public or private research centers.
L'archive ouverte pluridisciplinaire HAL, est destinée au dépôt et à la diffusion de documents scientifiques de niveau recherche, publiés ou non, émanant des établissements d'enseignement et de recherche français ou étrangers, des laboratoires publics ou privés. 


\title{
Mass Spectrometric Study of Thermolysis Mechanism of Metal Acetylacetonates Vapour
}

\author{
A.F. Bykov, A.E. Turgambaeva, I.K. Igumenov and P.P. Semyannikov \\ Institute of Inorganic Chemistry, Lavrentieva, 3, Novosibirsk, 630090, Russia
}

\begin{abstract}
The processes of thermal decomposition of aluminium(III) and scandium(III) acetylacetonates (Al(aa) 3 and $\mathrm{Sc}(\mathrm{aa})_{3}$ ) were investigated in the $160-650^{\circ} \mathrm{C}$ temperature range using a high-temperature molecular beam source with mass spectrometric sampling of the gas phase composition directly at the outlet from the reaction zone. A scheme of thermal decomposition of aluminium(III) and scandium(III) acetylacetonates vapour is suggested. It is established that the common mechanism of thermolysis of these complexes is due to the commonness of electronic structure of ions $\mathrm{Mg}^{2+}, \mathrm{Al}^{3+}, \mathrm{Sc}^{3+}$ and $\mathrm{Hf}^{4+}$. According to the scheme, the process proceeds along three parallel routes, one of them being possible only for complexes possessing more than two ligands; in this case the gaseous products resulting from cyclic dimerization of ligand fragments are formed. The influence of oxygen and hydrogen on the composition of the gaseous products and the mechanism of thermolysis of the complexes vapour are also established. From temperature curves, the effective values of kinetic parameters in Arrhenius equation are calculated for the first order reaction.
\end{abstract}

\section{INTRODUCTION}

The wide application of metal $\beta$-diketonates as precursors in CVD processes [1] for the purposes of electronics, optics, acoustics etc. is a significant incentive to study thermal decomposition of these compounds. Metal $\beta$-diketonates have the general formula $M\left(R^{1} C(O) C H C(O) R^{2}\right)_{n}$, where $M$ is the atom of the metal, $R^{1}$ and $R^{2}$ are the substituents in the ligand $\left(R^{1}=R^{2}=C_{3}\right.$ for acetylacetonates), and $n$ is the number of ligands in the complex. Reactions used to prepare coatings of definite composition are complicated heterogeneous processes. Therefore it is important to know not only their kinetic parameters but also the gaseous products and the stages of the process where these products are formed. It is also important in practice to know how various gas environment influences thermal decomposition reactions.

Investigation of thermal decomposition of $\mathrm{Al}(\mathrm{aa})_{3}$ has received much attention in the literature. One of the first works where along with $\mathrm{Al}(\mathrm{aa})_{3}$ a number of other metal acetylacetonates have been investigated was published in 1958 [2]. The test substance sealed in an ampoule was exposed at a certain temperature and after cooling the quantitative and qualitative composition of gaseous products of reaction was determined by mass spectrometric method. Side-processes such as the interaction of thermolysis products with condensed species and the gas phase of the initial substance was a disadvantage of that investigation. Although in a similar work [3] dated 1992 its authors avoided the interaction of decomposition products with the condensed phase, they could obtain only the information about the secondary products of thermal decomposition.

Purely mass spectrometric approach to investigation of thermolysis processes is also known [4] where an attempt was made to draw an analogy between decomposition under the electron impact (or other type of excitation) and thermal decomposition. However, this analogy requires convincing experimental proof.

Complexes of $\mathrm{Sc}(\mathrm{aa})_{3}, \mathrm{Mg}(\mathrm{aa})_{2}$ and $\mathrm{Hf}(\mathrm{aa})_{4}$ have been considerably less investigated but their thermal decomposition, as will be shown below, rums along the same common mechanism. 
In the present work, the thermal behaviour of aluminium and scandium acetylacetonates vapour was investigated in close detail. The magnesium and hafnium complexes were taken in order to study the influence of stoichiometry of the complex on the thermolysis mechanism.

\section{EXPERIMENTAL}

For study of the processes of thermal decomposition of the compounds, we used the system based on the MSKh-6 (USSR) time-of-flight mass spectrometer, with a mass number range up to $3000 \mathrm{~m} / \mathrm{z}$ and a mass resolution of $3 \times 10^{-3}$ a.m. The energy of ionizing electrons was about $70 \mathrm{eV}$. The mass spectrometer served for monitoring the gas phase composition at the outlet of a thermal reactor where the vapour of the compound under study was decomposed. The thermal reactor similar to that described in reference [5] represented a two-temperature variant of the Knudsen sell and had the same scheme of experimental arrangement and procedure described earlier [6]. The design of the arrangement allowed various additional gases to be admitted into the thermal reactor.

The information about the mechanism of thermolysis of metal acetylacetonates vapour under different conditions was obtained from the temperature dependence of the ion peak intensities of the mass spectra. To ensure reproducibility of the data on thermal conversion of the complexes, the reactor walls were previously coated with a film formed by thermolysis of the starting compound. Temperatures of the evaporation chamber in our experiments were about $125^{\circ} \mathrm{C}$ for $\mathrm{Al}(\mathrm{aa})_{3}$, from 128 up to $141^{\circ} \mathrm{C}$ for $\mathrm{Sc}(\mathrm{aa})_{3}$, $216^{\circ} \mathrm{C}$ for $\mathrm{Mg}(\mathrm{aa})_{2}$ and $170^{\circ} \mathrm{C}$ for $\mathrm{Hf}(\mathrm{aa})_{4}$. The minimum temperature of the reaction chamber was $5-10^{\circ} \mathrm{C}$ higher than that of the evaporation chamber.

\section{RESULTS AND DISCUSSION}

\subsection{Mass spectra of $\mathrm{Al}(\mathrm{aa})_{3}$ and $\mathrm{Sc}(\mathrm{aa})_{3}$}

The complexes of aluminium and scandium with acetylacetone have similar mass spectra that are characteristic for the complexes of the third group of metals with $\beta$-diketones [7]. Both complexes give a molecular ion that is cleaved with formation of $\left[\mathrm{M}(\mathrm{aa})_{2}\right]^{+}$showing the maximum intensity. The fragmentation of $\left[\mathrm{M}(\mathbf{a a})_{2}\right]^{+}$proceeds in several directions: with the elimination of even-electron particles $(82,84,58,42,18)$ and with the elimination of the ligand-radical resulting in $[\mathrm{M}(\mathrm{aa})]^{+}$.

Of interest is the set of metal-containing peaks with low $\mathrm{m} / \mathrm{z}$. There are more abundant than those reported in the literature. In particular, mass spectra of $\mathrm{Al}(\mathrm{aa})_{3}$ and $\mathrm{Sc}(\mathrm{aa})_{3}$ reported in $[4,8]$ show no evidence of ions related to the elimination of acetone and a species with molecular weight 84 (with the formation of $\left[\mathrm{M}(\mathrm{aa}) \mathrm{CH}_{3}\right]^{+}$, although this ion was observed for $\mathrm{Ga}(\mathrm{aa})_{3}$ [9] ).

\subsection{Thermolysis of Al (aa) $)_{3}$ and $S c(a a)_{3}$ vapour}

In Fig. 1(a,b) is shown the temperature dependence of ion peak intensities for $\mathrm{Al}(\mathrm{aa})_{3}$ and $\mathrm{Sc}(\mathrm{aa})_{3}$ mass spectra reflecting the change in the gas phase composition at the output of the thermal reactor. It is seen that the process of thermal decomposition of the complexes has a well-defined threshold character; i.e., when a certain temperature $\left(290 \pm 10^{\circ} \mathrm{C}\right.$ for $\mathrm{Al}(\mathrm{aa})_{3}$ and $360 \pm 10^{\circ} \mathrm{C}$ for $\left.\mathrm{Sc}(\mathrm{aa})_{3}\right)$ is attained the intensity of metal-containing ion peaks begins to decrease. Note that no disproportionation of the metal-containing ion peak intensities with temperature was observed, i.e. all metal-containing ions have the same molecular precursor. Therefore in all figures we characterize the quantity of the initial component by the most abundant $\left[\mathrm{M}(\mathrm{aa})_{2}\right]^{+}$ion peak.

When the quantity of the initial complex in the output of the thermal reactor decreases, the peaks of gaseous products of reaction such as acetone $(\mathrm{m} / \mathrm{z} 58)$, free ligand $(\mathrm{m} / \mathrm{z} 100)$, ketene 
intensity, rel. units

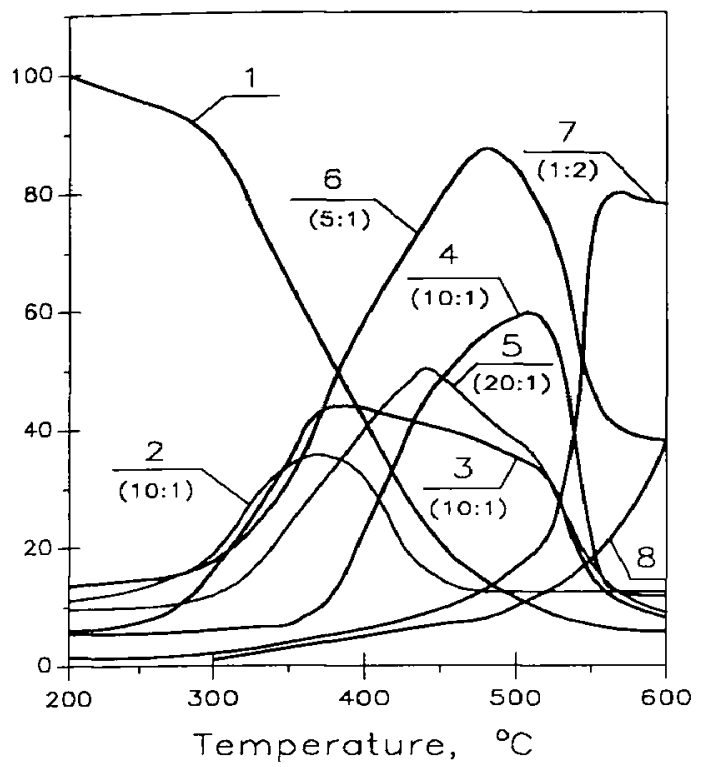

Intensity, rel. units

b)

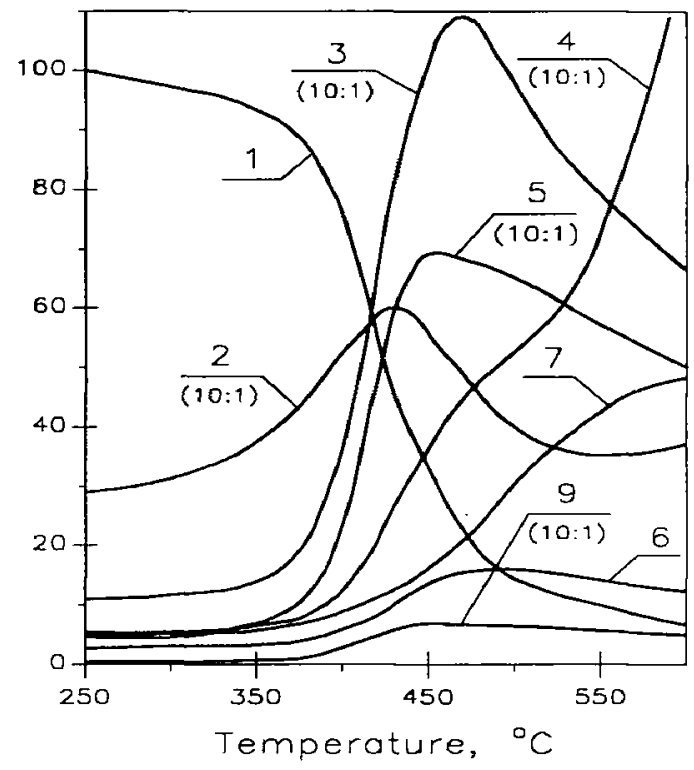

Figure 1: Temperature dependence of ion peak intensities corresponding to the main gaseous products of thermolysis of aluminium(III) a) and scandium(III) b) acetylacetonates vapours: $\left[\mathrm{M}(\mathrm{aa})_{2}\right]^{+}(1),[\mathrm{Haa}]^{+}(2),\left[\mathrm{C}_{3} \mathrm{H}_{6} \mathrm{O}^{+}(3),\left[\mathrm{C}_{5} \mathrm{H}_{6} \mathrm{O}\right]^{+}(4)\right.$, $\left[\mathrm{C}_{8} \mathrm{H}_{10} \mathrm{O}\right]^{+}(5),\left[\mathrm{H}_{2} \mathrm{O}\right]^{+}(6),[\mathrm{CO}]^{+}(7),\left[\mathrm{H}_{2}\right]^{+}(8),\left[\left(\mathrm{C}_{5} \mathrm{H}_{6} \mathrm{O}\right)_{2}\right]^{+}(9)$. The scale is in brackets.

$(\mathrm{m} / \mathrm{z} 42)$, water and species with $\mathrm{m} / \mathrm{z} 82,122$ and 164 arise in the mass spectrum. The content of carbon monoxide in the gaseous products of reaction increases with temperature. The ion peak with $\mathrm{m} / \mathrm{z} 82$ corresponds to a species with the formula $\mathrm{C}_{5} \mathrm{H}_{6} \mathrm{O}$ whose formation could be explained by the rupture of "carbon-enolic oxygen" bond and migration of hydrogen to enolic oxygen atom. The $\mathrm{m} / \mathrm{z} 122$ and 164 ion peaks correspond to species with formulae $\mathrm{C}_{8} \mathrm{H}_{10} \mathrm{O}$ and $\left(\mathrm{C}_{5} \mathrm{H}_{6} \mathrm{O}\right)_{2}$, respectively. The formation of a species $\left(\mathrm{C}_{5} \mathrm{H}_{6} \mathrm{O}\right)_{2}$ is, in our opinion, the result of cyclic dimerization of two adjacent ligand fragments formed due to the opening of chelate cycles, breaking of the "carbon-enolic oxygen" boud and migration of hydrogen from methyl group to enolic oxygen of the adjacent ligand. The cyclic diketone formed transforms upon subsequent elimination of ketene, $\mathrm{CH}_{2} \mathrm{CO}$, into a more stable compound 3,5dimethylphenol $(\mathrm{m} / \mathrm{z} 122)$. Patterns of thermal decomposition of $\mathrm{Al}(\mathrm{aa})_{3}$ and $\mathrm{Sc}(\mathrm{aa})_{3}$ vapour can be shown schematically:

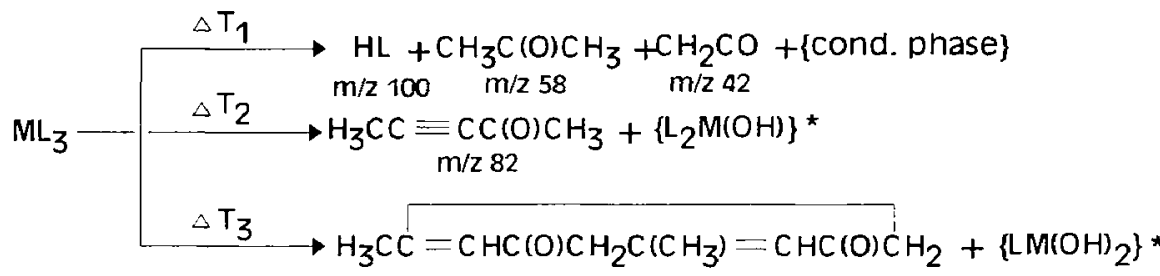

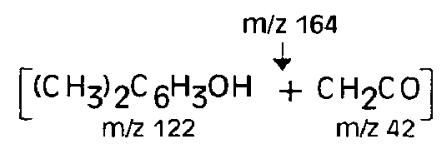

where $\mathrm{M}=\mathrm{Al}, \mathrm{Sc} ; \mathrm{L}=\mathrm{C}_{5} \mathrm{H}_{7} \mathrm{O}_{2}$; and * - postulated species. Liberating water and the products of ligand destruction into the gas phase, the rest of the complex will form the solid phase. 
A distinctive feature of $\mathrm{Al}(\mathrm{aa})_{3}$ vapour thermolysis is the maximum at $520^{\circ} \mathrm{C}$ on the curve corresponding to the species $\mathrm{C}_{5} \mathrm{H}_{6} \mathrm{O}$. The thermolysis process is displace in the direction of the elementary products of reaction: carbon monoxide and molecular hydrogen. It should be noted that it is difficult to explain the occurrence of ion $\left[\mathrm{H}_{2}\right]^{+}$in the mass spectrum by fragmentation of hydrocarbon products of reaction under the electron impact. Hydrogen is also recorded among the gaseous products of $\mathrm{Sc}(\mathrm{aa})_{3}$ vapour thermolysis. The ratio of intensity of the ion peak $\left[\mathrm{H}_{2}\right]^{+}$to $\left.[\mathrm{M(aa})_{2}\right]^{+}$for $\mathrm{Al}(\mathrm{aa})_{3}$ is approximately 5 times less than for $\mathrm{Sc}(\mathrm{aa})_{3}$. Present among the products of high-temperature decomposition of $\mathrm{Al}(\mathrm{aa})_{3}$ vapour is also methane. A peak with $\mathrm{m} / \mathrm{z} 164$ was observed among the products of $\mathrm{Al}(\mathrm{aa})_{3}$ vapour thermolysis but its low intensity has not allowed the determination of the temperature dependence.

From the above, a high content of carbon in the condensed phase is to be expected due to ligand fragment decomposition in the processes of chemical vapour deposition of films. It is known from the literature [10] that carbon content in metal oxide films is insignificant when a CVD process is conducted in oxygen promoting the removal of carbon containing impurities from the film.

\subsection{Thermolysis of $\mathrm{Al}(\mathrm{aa})_{3}$ and $\mathrm{Sc}(\mathrm{aa})_{3}$ vapour in oxygen}

The temperature dependence of ion peak intensities of the mass spectra obtained for $\mathrm{Al}$ and $\mathrm{Sc}$ acetylacetonate vapour thermolysis in oxygen is shown in Fig. $2(\mathrm{a}, \mathrm{b})$. It is immediately seen that the presence of $\mathrm{O}_{2}$ decreases the threshold temperature down to $260 \pm 10^{\circ} \mathrm{C}$ for $\mathrm{Al}(\mathrm{aa})_{3}$ and down to $310 \pm 10^{\circ} \mathrm{C}$ for $\mathrm{Sc}(\mathrm{aa})_{3}$, which is usually the case. Species with molecular weights 82,122 and 164 are absent from the products of reaction, and the relative quantity of free ligand and acetone is lower in comparison with thermolysis in vacuum (with the exception of acetylacetone for $\mathrm{Al}(\mathrm{aa})_{3}$ ).

The main products of the complexes thermolysis in oxygen are $\mathrm{CO}_{2}, \mathrm{CO}, \mathrm{H}_{2} \mathrm{O}$ and, in the case of $\mathrm{Al}(\mathrm{aa})_{3}$, methane. With rising temperature the concentration of $\mathrm{CO}$ grows faster than that of $\mathrm{CO}_{2}$. The increase of oxygen content decreases the ratio and allows one to expect a reduction of carbon impurities in the coating.
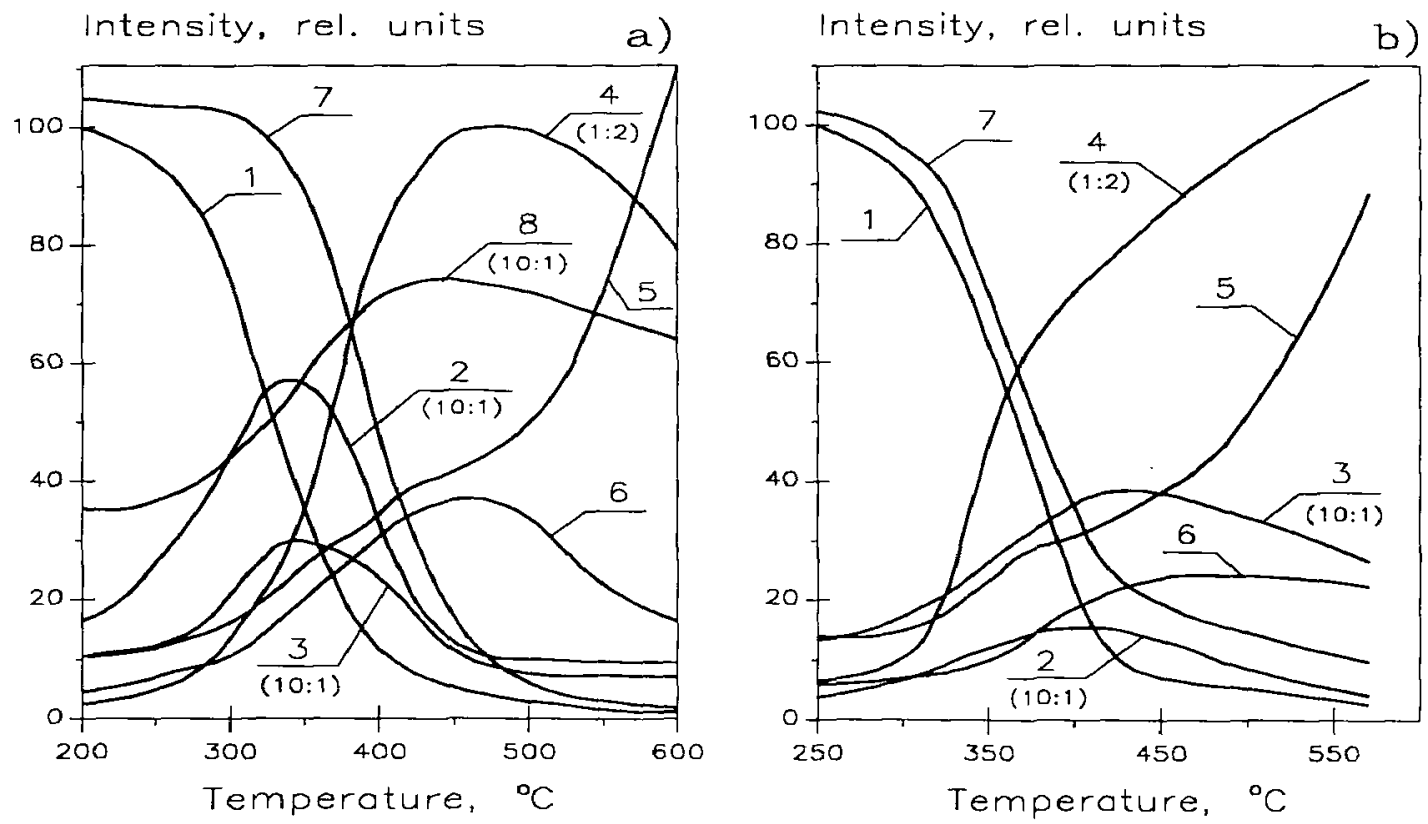

Figure 2: Temperature dependence of ion peak intensities corresponding to the main gaseous products of thermolysis of aluminium(III) a) and scandiun(III) b) acetylacetonate vapours in oxygen: $\left.\left.\left[\mathrm{M}(\mathrm{aa})_{2}\right]^{+}(1),[\mathrm{Haa}]^{+} 2\right),\left[\mathrm{C}_{3} \mathrm{H}_{6} \mathrm{O}\right]^{+} 3\right),\left[\mathrm{CO}_{2}\right]^{+}$ (4), $\left[\mathrm{CO}^{+}(5),\left[\mathrm{H}_{2} \mathrm{O}\right]^{+}(6) \cdot\left[\mathrm{O}_{2}\right]^{+}(7) \cdot\left[\mathrm{CH}_{4}\right]^{+}(8)\right.$. The scale is in brackets. 


\subsection{Thermolysis of $\mathrm{Al}(\mathrm{aa})_{3}$ and $\mathrm{Sc}(\mathrm{aa})_{3}$ vapour in hydrogen}

From the practical point of view this case is of little importance since formation of metal films by thermolysis in hydrogen is not expected owing to thermodynamic restrictions. However, it is of interest to study the influence of hydrogen on the mechanism of the process.
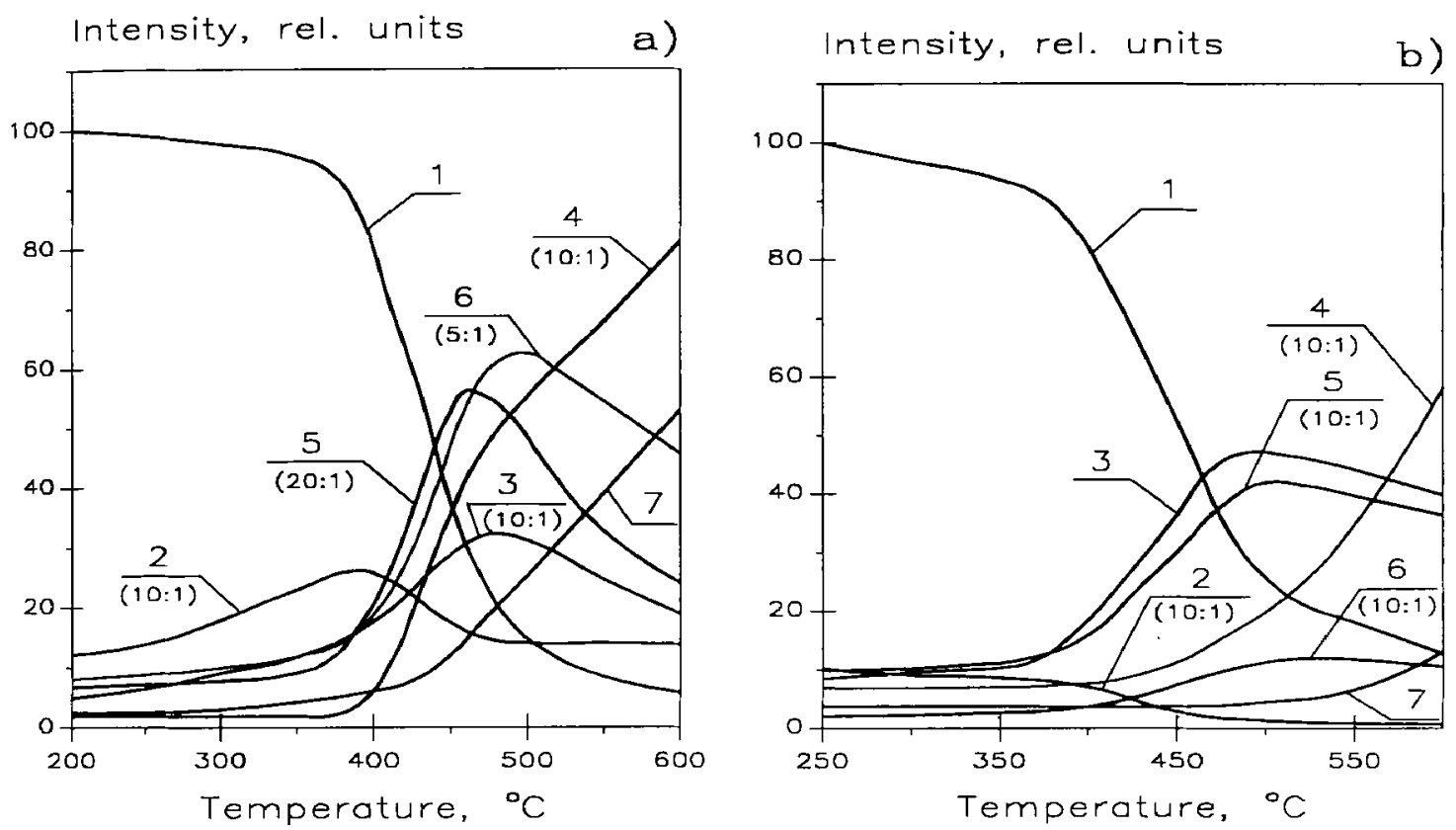

Figure 3: Temperature dependence of ion peak intensities corresponding to the main gaseous products of thermolysis of aluminium(III) a) and scandium(III) b) acetylacetonate vapours in hydrogen: $\left[\mathrm{M}(\mathrm{aa})_{2}\right]^{+}(1),[\mathrm{Haa}]^{+}(2),\left[\mathrm{C}_{3} \mathrm{H}_{6} \mathrm{O}\right]^{+}(3)$, $\left[\mathrm{C}_{5} \mathrm{H}_{6} \mathrm{O}\right]^{+}(4),\left[\mathrm{C}_{8} \mathrm{H}_{10} \mathrm{O}\right]^{+}(5),\left[\mathrm{H}_{2} \mathrm{O}\right]^{+}(6),[\mathrm{CO}]^{+}(7)$. The scale is in brackets

In Fig. 3 (a, b) temperature curves obtained for thermolysis of $\mathrm{Al}$ and $\mathrm{Sc}$ acetylacetonates in hydrogen are shown. They indicate the increase of the threshold temperature up to $370 \pm 10^{\circ} \mathrm{C}$ both for $\mathrm{Al}(\mathrm{aa})_{3}$ and for $\mathrm{Sc}(\mathrm{aa})_{3}$. A small increase of the threshold temperature for thermolysis in hydrogen has previously been observed by us for $\operatorname{Ir}(\mathrm{aa})_{3}, \mathrm{Rh}(\mathrm{aa})_{3}$ [11], and $\mathrm{Ru}(\mathrm{aa})_{3}$ [12] vapours; however such a significant increase for $\mathrm{Al}(\mathrm{aa})_{3}$. is observed here for the first time. The increase of the threshold temperature of thermolysis can be explained by passivation of surface owing to adsorption of hydrogen molecules. Note also that a significant growth of $\mathrm{CO}$ content for $\mathrm{Sc}(\mathrm{aa})_{3}$ thermal decomposition in hydrogen was observed only at temperatures above $690-700^{\circ} \mathrm{C}$

\subsection{Kinetic parameters of thermolysis of $\mathrm{Al}(\mathrm{aa})_{3}$ and $\mathrm{Sc}(\mathrm{aa})_{3}$ vapour}

On the basis of the temperature dependencies obtained for the starting components and assuming irreversibility and the first-order kinetics for thermolysis of the complex vapours, it is possible to calculate the parameters in Arrhenius equation for each case. The same is also possible in the presence of a gaseous reagent if the order of reaction for one gas is close to zero.

With these assumptions kinetic parameters obtained are listed in Table 1. The decrease of kinetic parameters values observed for $\mathrm{Sc}(\mathrm{aa})_{3}$ thermolysis in hydrogen has also been found for the abovementioned iridium, rhodium and ruthenium acetylacetonates. However, an increase of kinetic parameters occurs on thermolysis of $\mathrm{Al}(\mathrm{aa})_{3}$ in hydrogen. 
Table 1: Kinetic parameters and threshold temperatures for thermal decomposition of $\mathrm{Al}(\mathrm{aa})_{3}$ and $\mathrm{Sc}(\mathrm{aa})_{3}$

\begin{tabular}{|l|c|c|c|c|c|c|}
\hline Compound & \multicolumn{3}{|c|}{$\mathrm{Al}(\mathrm{aa})_{3}$} & \multicolumn{3}{c|}{$\mathrm{Sc}(\mathrm{aa})_{3}$} \\
\hline Conditions & "vacuum" & oxygen & hydrogen & "vacuum" & oxygen & hydrogen \\
\hline $\begin{array}{l}\text { Threshold temp., } \\
(\mathrm{T} \pm 10)^{\circ} \mathrm{C}\end{array}$ & 290 & 260 & 370 & 360 & 310 & 370 \\
\hline $\begin{array}{l}\text { Activation energy, } \\
\left(\mathrm{E}_{\mathrm{a}}\right) \mathrm{kJ} / \mathrm{mol}\end{array}$ & $83.8 \pm 3.0$ & -- & $170.2 \pm 6.1$ & $147.5 \pm 5.9$ & -- & $127.5 \pm 3.4$ \\
\hline $\begin{array}{l}\text { Preexponential factor, } \\
\left(\mathrm{K}_{\mathrm{a}}\right)^{-1}\end{array}$ & $3.4 * 10^{7}$ & -- & $2.6 * 10^{13}$ & $6.5 * 10^{11}$ & -- & $1.1 * 10^{10}$ \\
\hline
\end{tabular}

\subsection{Thermolysis of $\mathrm{Mg}(\mathrm{aa})_{2}$ and $\mathrm{Hf}(\mathrm{aa})_{4}$ vapour}

The formation of species $\mathrm{C}_{5} \mathrm{H}_{6} \mathrm{O}$ as a product of thermolysis of $\mathrm{Al}$ and $\mathrm{Sc}$ acetylacetonates can be explained by the high of energy of "metal-oxygen" bond in the complex. However, it is difficult to understand under that conditions the cyclic diketone $\left(\mathrm{C}_{5} \mathrm{H}_{6} \mathrm{O}\right)_{2}$ is formed. We believe that the conditions for this species formation are the following:

- opening of chelate cycle of the complex as a result of thermal excitation (i.e. changing of ligand coordination from bidentate to monodentate);

- "metal-oxygen" bond in the complex stronger than "carbon-oxygen" bond;

- availability of three or more ligands in a molecule of the complex. For the proof of the last assumption we have chosen acetylacetonates of magnesium(II) and hafnium(IV) whose cations are electronic analogs.

The full mass spectra of $\mathrm{Mg}(\mathrm{aa})_{2}$ and $\mathrm{Hf}(\mathrm{aa})_{4}$ were investigated at two different temperatures. The mass spectra were recorded at a temperature when thermal decomposition was absent $\left(220^{\circ} \mathrm{C}\right)$, and at a temperature when peaks of metal-containing ions practically disappeared from mass spectrum $\left(700^{\circ} \mathrm{C}\right.$ for $\mathrm{Mg}(\mathrm{aa})_{2}$ and $460^{\circ} \mathrm{C}$ for $\mathrm{Hf}(\mathrm{aa})_{4}$ ). The $\mathrm{C}_{5} \mathrm{H}_{6} \mathrm{O}$ species (characteristic peaks $\mathrm{m} / \mathrm{z} 53$ and 82 ) is observed in thermolysis products of both compounds while the peaks of ions with $\mathrm{m} / \mathbf{z} 107,122,149$ and 164 corresponding to $\mathrm{C}_{8} \mathrm{H}_{10} \mathrm{O}$ and $\left(\mathrm{C}_{5} \mathrm{H}_{6} \mathrm{O}\right)_{2}$ species are present solely among the products of $\mathrm{Hf}(\mathrm{aa})_{4}$ vapour decomposition.

Note that the thermal stability of $\mathrm{Hf}(\mathrm{aa})_{4}$ is lower and that of $\mathrm{Mg}(\mathrm{aa})_{2}$ is higher than the thermal stability of $\mathrm{Al}(\mathrm{aa})_{3}$ and $\mathrm{Sc}(\mathrm{aa})_{3}$ vapours. In addition, the molecular peak is absent in the mass spectrum of $\mathrm{Hf}(\mathrm{aa})_{4}$ and the intensity of $\left[\mathrm{Hf}(\mathrm{aa})_{3}\right]^{+}$peak is the maximum.

Thus it follows from the presented data that the distinctive feature of thermolysis of the investigated complexes of acetylacetone with metals of $3 \mathrm{~A}$ and $4 \mathrm{~A}$ group of the Periodic system is the formation of a cyclic diketone as the product of reaction. For complexes with the $2 \mathrm{~A}$ group metals the formation of such species appears to become impossible. The formation of cyclic species on thermolysis of $\mathrm{Al}, \mathrm{Sc}$ and $\mathrm{Hf}$ acetylacetonates vapour is shown in the scheme:

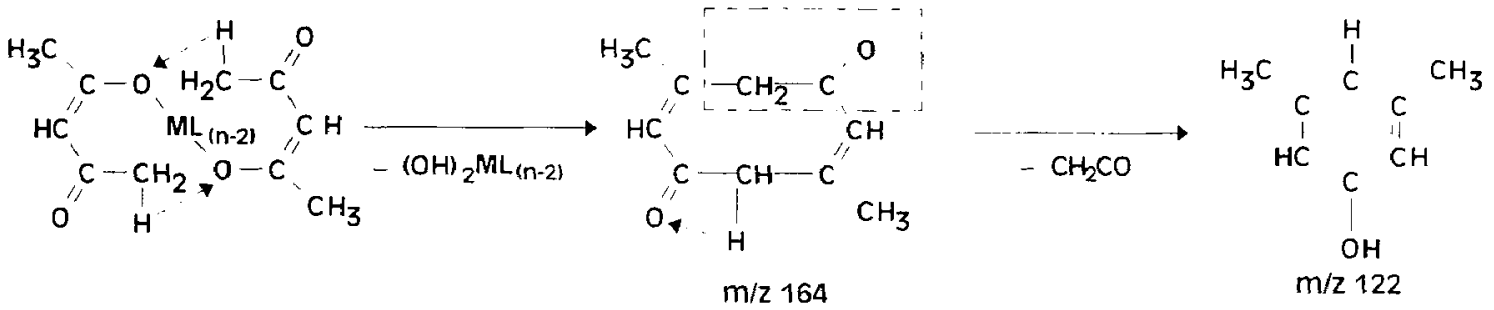

where $\mathbf{M}=\mathrm{Al}$, Sc, Hf $\mathrm{n}=3,4 ; \mathrm{L}=\mathrm{C}_{5} \mathrm{H}_{7} \mathrm{O}_{2}$. 
The occurrence of a species with $\mathrm{m} / \mathrm{z} 122$ in the mass spectrum can be explained by further thermal decomposition of the cyclic diketone. Formation of this species from fragmentation under electronic impact is not excluded. The pattern of formation of metal oxides in the condensed phase is seen from the scheme:

$\left\{2 \mathrm{M}(\mathrm{OH})_{2} \mathrm{C}_{5} \mathrm{H}_{7} \mathrm{O}_{2}\right\} *$ surface $=\mathrm{M}_{2} \mathrm{O}_{3}$ (cond. phase) $+2 \mathrm{C}_{5} \mathrm{H}_{6} \mathrm{O}$ (gas phase) $+3 \mathrm{H}_{2} \mathrm{O}$ (gas phase) $(\mathrm{M}=\mathrm{Al}, \mathrm{Sc})$;

$\left\{\mathrm{M}(\mathrm{OH})_{2}\left(\mathrm{C}_{5} \mathrm{H}_{7} \mathrm{O}_{2}\right)_{2}\right\} *$ surface $=\mathrm{MO}_{2}$ (cond. phase) $+2 \mathrm{C}_{5} \mathrm{H}_{6} \mathrm{O}$ (gas phase) $+2 \mathrm{H}_{2} \mathrm{O}$ (gas phase) $(\mathrm{M}=\mathrm{Hf})$.

\section{CONCLUSION}

The investigations of $\mathrm{Al}, \mathrm{Sc}, \mathrm{Mg}$ and $\mathrm{Hf}$ acetylacetonates vapour thermolysis using a mass spectrometric method has allowed information to be obtained about primary gaseous products of reaction and to offer a mechanism of thermolysis. A peculiarity of the process is that among the products of reaction there are species formed as a result of cyclic dimerization of ligand fragments from the complexes. It has been shown that such process can occur in the case of the number of ligands in the complex exceeding two. Similar data on thermolysis of yttrium(III) dipivaloylmethanate [13] and zirconium(IV) trifluoracetylacetonate [14] obtained by us earlier suggest that both in the case of bulky hydrocarbon radicals $\left(R^{1}=R^{2}=C\left(C_{3}\right)_{3}\right)$ on the ligand and fluorinated substituents $\left(R^{1}=C_{3}, R^{2}=C_{3}\right)$ the formation of cyclic species does not occur.

The influence of oxygen and hydrogen on $\mathrm{Al}$ and $\mathrm{Sc}$ acetylacetonates vapour thermolysis has been investigated. It is established that hydrogen does not practically influence the character of the process and the main products of decomposition, while oxygen causes significant oxidation of the organic ligand in the complex and increases the rate of decomposition.

\section{References}

[1] Films and coatings deposition by metalorganic compounds decomposition (Ed. by Razurvaev G.A., Nauka, Moscow, 1981) pp.266-275 (in Russian).

[2] Hoene B.J.V., Charles R.G. and Hickam W.M., J. Phys. Chem. 62 (1958) 1098-1101.

[3] Minkina V.G., Neorg. Materialy 29 (1993) 1565-1566 (in Russian).

[4] Bogdanov V.A., Volkov S.V., Gerasimchuk A.I., Mazurenko E.A. and Schelokov R.N., Koord. Khim. 10 (1984) 1346-1352 (in Russian).

[5] Grankin V.M. and Semyannikov P.P., Pribori i tekhnika experimenta 4 (1991) 129 (in Russian).

[6] Bykov A.F., Semyannikov P.P. and Igumenov I.K.,J. Thermal Anal. 38 (1992) 1463-1475.

[7] Gerbeleu N.V. and Indrichan K.M., Mass spectrometry of coordination compounds (Shtiintsa, Kishinev, 1984) pp.51-72 (in Russian)

[8] Macdonald C.G. and Shannon J.S., Aust. J. Chem. 19 (1966) 1545-1566.

[9] Charalambous J., Gossett R.J., Johri M.H. and Kensett M.J., Inorg. Chim. Acta 22 (1977) 101-105.

[10] Razuvaev G.A., Gribov B.G., Domrachev G.A. and Salamatin B.A., Metalorganic compounds in electronics (Nauka, Moscow, 1972) pp.311-369 (in Russian).

[11] Isakova V.G., Semyannikov P.P., Grankin V.M. and Igumenov I.K., Koord. Khim. 14 (1988) 57-62 (in Russian).

[12] Unpublished results.

[13] Bykov A.F., Semyannikov P.P. and Igumenov I.K.,J. Thermal Anal. 38 (1992) 1477-1486.

[14] Bykov A.F., Igumenov I.K., Lisoivan V.I., Asanov I.P., Yushina I.V. and Aupov B.M., Zh. Neorg. Khim. 39 (1994) 2053-2060 (in Russian). 